\title{
Thermal Reactivity of Mixtures of VDDT Lubricant and Simulated Hanford Tank 241-SY-101 Waste
}

\author{
R. D. Scheele \\ F. E. Panisko \\ R. L. Sell
}

September 1996

Prepared for

the U.S. Department of Energy

under Contract DE-AC06-76RLO 1830

Pacific Northwest Laboratory

Richland, Washington 99352 


\section{DISCLAIMER}

This report was prepared as an account of work sponsored by an agency of the United States Government. Neither the United States Government nor any agency thereof, nor any of their employees, make any warranty, express or implied, or assumes any legal liability or responsibility for the accuracy, completeness, or usefulness of any information, apparatus, product, or process disclosed, or represents that its use would not infringe privately owned rights. Reference herein to any specific commercial product, process, or service by trade name, trademark, manufacturer, or otherwise does not necessarily constitute or imply its endorsement, recommendation, or favoring by the United States Government or any agency thereof. The views and opinions of authors expressed herein do not necessarily state or reflect those of the United States Government or any agency thereof. 


\section{DISCLAIMER}

Portions of this document may be illegible in electronic image products. Images are produced from the best available original document. 


\section{Summary}

To predict whether the Polywater ${ }^{\star} \mathrm{G}$ lubricant residue remaining in the velocity, density, and temperature tree (VDTT) and the waste in Tank 241-SY-101 (101SY) will be chemically compatible with wastes in 101SY when two VDTTs are removed from 101SY, the Pacific Northwest National Laboratory measured the thermal reaction sensitivity of the lubricant residue. This residue is a simulated 101SY waste containing the organic surrogate trisodium hydroxyethyl-ethylenediaminetriacetate $\left(\mathrm{Na}_{3} \mathrm{HEDTA}\right)$ and two simulated potential waste and lubricant residue mixtures containing 10 and $90 \mathrm{wt} \%$ lubricant residue. These studies using accelerating rate calorimetry found that the residue did not react at a rate exceeding $0.1 \mathrm{~J} / \mathrm{min} / \mathrm{g}$ mixture up to $190^{\circ} \mathrm{C}$ with the simulated $101 \mathrm{SY}$ waste containing $\mathrm{Na}_{3} \mathrm{HEDTA}$ as the organic surrogate. Also, the dried lubricant residue did not decompose exothermically at a rate exceeding $0.1 \mathrm{~J} / \mathrm{min} / \mathrm{g}$. Using guidelines used by the chemical industry, these results indicate that the lubricant residue should not react at a significant rate with the waste in 101SY when added to the waste at $60^{\circ} \mathrm{C}$ or when the mixture cools to the waste's temperature of $48^{\circ} \mathrm{C}$. 


\section{Glossary}

101SY Tank 241-SY-101

ALARA as low as reasonably achievable

ARC

DOE

accelerating rate calorimetry

DSC

U.S. Department of Energy

DTA

differential scanning calorimetry

ED3A

differential thermal analysis

EDTA

ethylenediamietriacetate

IR

ethylenediaminetetraacetate

$\mathrm{Na}_{3} \mathrm{HEDTA}$

infrared

NIDA

trisodium hydroxyethyl-ethylenediaminetriacetate

NIST

nitrosoiminodiacetate

MSDS

National Institute of Standard Technology

NTA

Material Safety Data Sheet

RSST

nitrilotriacetate

TGA

reactive system screening tool

TOC

thermogravimetric analysis

total organic carbon

VDTT

velocity, density, and temperature tree 


\section{Contents}

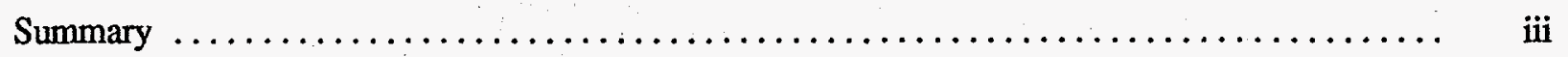

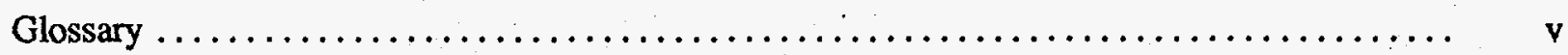

1.0 Introduction $\quad \ldots \ldots \ldots \ldots \ldots \ldots \ldots \ldots \ldots \ldots \ldots \ldots \ldots \ldots \ldots \ldots \ldots \ldots, 1.1$

2.0 Experimental Strategy $\ldots \ldots \ldots \ldots \ldots \ldots \ldots \ldots \ldots \ldots \ldots \ldots \ldots \ldots \ldots \ldots \ldots \ldots, 2.1$

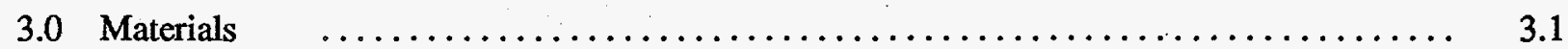

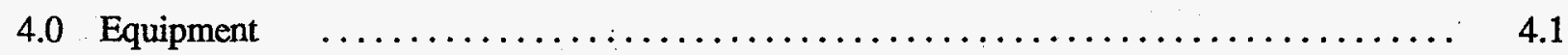

4.1 Accelerating Rate Calorimeter $\ldots \ldots \ldots \ldots \ldots \ldots \ldots \ldots \ldots \ldots \ldots \ldots \ldots, 4.1$

4.2 Differential Scanning Calorimetry and Differential Thermal Analysis ........... 4.4

4.3 Thermogravimetric Analysis $\ldots \ldots \ldots \ldots \ldots \ldots \ldots \ldots \ldots \ldots \ldots \ldots \ldots \ldots, 4.5$

5.0 Reactivity of Polywater and Simulated 101 SY/HEDTA $\ldots \ldots \ldots \ldots \ldots \ldots \ldots \ldots . \quad 5.1$

5.1. Thermal Behavior of Dried Polywater Lubricant $\ldots \ldots \ldots \ldots \ldots \ldots \ldots \ldots \ldots \ldots .5 .1$

5.2 Thermal Reactivity of Mixtures of Polywater ${ }^{\circledR}$ Residue and 101SY/HEDTA $\ldots \ldots \ldots \quad 5.2$

6.0 References $\quad \ldots \ldots \ldots \ldots \ldots \ldots \ldots \ldots \ldots \ldots \ldots \ldots \ldots \ldots \ldots \ldots \ldots \ldots \ldots \ldots \ldots \ldots \ldots \ldots, 6.1$

Appendix A: POLYWATER ${ }^{\infty}$ Lubricant G Material Safety Data Sheet $\ldots \ldots \ldots \ldots \ldots \ldots \ldots$ A.1 


\section{Tables}

3.1 Recipe-Based Dry Basis Composition of Simulated 101SY Waste Containing 2 wt\% TOC as $\mathrm{Na}_{3}$ HEDTA (Formulation SY1-SIM-92A [Bryan and Pederson 1994]) $\ldots \ldots \ldots \ldots \ldots$. 


\subsection{Introduction}

The velocity, density, and temperature trees (VDTT), VDTT-1B and VDTT-14A, are scheduled to be removed from the Hanford Tank 241-SY-101 (101SY). During the removal process, the VDTTs will be flushed with water to remove any waste that may be inside the VDTTs. Within each VDTT is a residue of the electrical cable lubricant called Polywater ${ }^{\star}$. When water is used to flush any waste from inside the VDTTs, it will also flush some/all of the lubricant residue from inside the VDTTs and onto as well as into the tank waste. There is a concern that the organic lubricant residue and the inorganic oxidants nitrate and nitrite present in the wastes in 101SY could react exothermically, leading to a propagating reaction within the waste.

During fabrication of the VDTTs, about $41.69 \mathrm{~L}$ (11 gallons) of Polywater ${ }^{\circledR}$ lubricant was used to assist in inserting all the velocity, density (pressure transducer), and temperature electrical cables inside the VDTTs. Subsequently, the lubricant was dried, leaving less than $500 \mathrm{~mL}$ (1 pint) of residue inside each VDTT. Since the lubricant is based on the Material Safety Data Sheet (MSDS) provided in Appendix A (98.4 wt\% water, $0.8 \mathrm{wt} \%$ isopropanol, $0.4 \mathrm{wt} \%$ carboxyvinyl polymer, and apparently $0.4 \mathrm{wt} \%$ other unidentified nonvolatile components), it is expected that only the $0.8 \mathrm{wt} \%$ carboxyvinyl polymer and other nonvolatile components will remain after drying. Vinyls are thermoplastics based on the $\mathrm{CH}_{2}=\mathrm{CH}_{x}$ structure.

As each VDTT is being removed from the tank, tens of liters of water at about $60^{\circ} \mathrm{C}\left(140^{\circ} \mathrm{F}\right)$ and $700 \mathrm{kPa}$ (100 psi) will be used to flush any waste from inside the VDTTs back into the tank where the waste is currently at or below $48^{\circ} \mathrm{C}\left(118^{\circ} \mathrm{F}\right)$. It is not known if the VDTTs contain any waste, but under "as low as reasonably achievable" (ALARA) guidance, it is assumed that waste is present. The waste may have entered the VDTTs via the failed pressure transducers attached to the walls of the VDTTs. The bottom of the VDTTs will be above the crust during the flushing operation, so some of water will contact the crust and the liquid waste through the hole in the crust left by the VDTTs.

This flush water will also remove some or all the Polywater ${ }^{\otimes}$ residue, introducing it on top of and into the stored waste. Because the lubricant is readily soluble in water (see attached), it is expected that most, if not all, of the residue will dissolve in the flush water and thus will contact the crust or enter the waste as a dilute solution: roughly $500 \mathrm{~mL}$ (1 pint) Polywater ${ }^{\$}$ residue in $110 \mathrm{~L}$ (30 gal). After several days, the water from the solution remaining on the crust will evaporate or be sorbed by the crust, leaving the lubricant residue either on the crust's surface or dissolved into the crust. The flush solution passing through the hole left by the VDTT removal should mix slowly with the liquid waste below the crust. This process will result in the introduction of an organic with an unknown sensitivity to reaction with nitrate and nitrite in the 101SY waste.

Because of the unknown chemical compatibility of the organic lubricant residue with the waste, there is a concern that when the $500 \mathrm{~mL}$ (1 pint) of vinyl polymer dissolved in $110 \mathrm{~L}$ ( $30 \mathrm{gal}$ ) of $60^{\circ} \mathrm{C}$ water is mixed with a large area of crust and with hundreds of liters of waste, an exothermic reaction could occur between the lubricant residue and the oxidizers in the waste. To determine if the small quantity of Polywater ${ }^{8}$ residue, compared to the quantities of waste and water, will react with the oxidants in the 
101SY waste or if the residue is compatible with the waste, the Pacific Northwest National Laboratory $(\mathrm{PNNL})^{(\mathbf{a})}$ studied the thermal reaction sensitivity of two mixtures of dried Polywater ${ }^{\infty}$ lubricant and a simulated 101SY waste containing trisodium hydroxyethylethylenediamine-triacetate $\left(\mathrm{Na}_{3} \mathrm{HEDTA}\right)$, using accelerating rate calorimetry (ARC).

This report provides the results of that experimental study to determine if hazardous reactions can occur between the lubricant residue and the oxidizers in 101SY waste. We have included, when available, related experiments from previous studies using ARC, differential scanning calorimetry (DSC), and simultaneous thermogravimetric analysis (TGA) and differential thermal analysis (DTA).

This work was requested by the Westinghouse Hanford Company, the operating contractor of the U.S. Department of Energy's (DOE) Hanford Site, and was funded by the DOE.

(a) Pacific Northwest National Laboratory is operated for the U.S. Department of Energy by Battelle under Contract DE-AC06-76RLO 1830. 


\subsection{Experimental Strategy}

To determine if Polywater ${ }^{\circ}$ lubricant residue will react with the oxidants in $101 \mathrm{SY}$ waste in an environment similar to that in 101SY waste, we used ARC to measure the thermally initiated reactivity of the dried lubricant residue, the simulated 10.1 SY waste containing $2 \mathrm{wt} \%$ total organic carbon (TOC) as $\mathrm{Na}_{3} \mathrm{HEDTA}$, and two mixtures of lubricant residue in a simulated $101 \mathrm{SY}$ waste. The temperatures were up to those exceeding the temperatures expected during and after the VDTT removal operation. The two mixtures, 10 and $90 \mathrm{wt} \%$ residue in simulated $101 \mathrm{SY}$ waste mixtures, were formulated to provide two extreme residue concentrations that may exhibit detectable reactivity. We used the same 101SY simulant used in our earlier oil and $101 \mathrm{SY}$ waste compatibility studies ${ }^{(2)}$. The experiments were run up to $200^{\circ} \mathrm{C}$, bounding the $60^{\circ} \mathrm{C}$ maximum temperature that the waste and residue should experience either during the mixing process or later after it has cooled to the waste's temperature of $48^{\circ} \mathrm{C}\left(118^{\circ} \mathrm{F}\right)$.

(a) R. D. Scheele, L. L. Burger, and R. L. Sell. 1995. Study of Replacement Pump Oil Compatibility with Waste Stored in Hanford Underground Storage Tank 241-SY-101. PNLMIT:013195, Pacific Northwest Laboratory, Richland, Washington. 


\subsection{Materials}

We prepared two dried mixtures of a simulated 101SY waste and Polywater ${ }^{\star}$ lubricant residue at 10 and $90 \mathrm{wt} \%$ residue. We used Polywater ${ }^{\circ} \mathrm{G}$ lubricant made by the same manufacturer and of the same grade as used in the VDTTs. The simulated 101SY waste selected for use was prepared using a recipe developed by Bryan and Pederson (1994), based on total organic carbon and inorganic chemical analyses of the waste stored in 101SY, and HEDTA, one of the original organics present in the waste stored in 101SY (Delegard 1980), was used.

Before preparing the two mixtures, we confirmed the amount of nonvolatiles in the lubricant by drying four $40-\mathrm{g}$ aliquots in a $65^{\circ} \mathrm{C}$ drying oven and analyzing two $50-\mathrm{mg}$ aliquots using TGA/DTA; the TGA also provided information about the temperatures that would be required to dry the lubricant to yield a dry residue. The former method yielded $0.85,0.86,0.87$, and $0.84 \mathrm{wt} \%$ nonvolatiles, and the TGA gave 0.77 and $0.70 \mathrm{wt} \%$; the average TGAs are presented in Figure 3.1. Though differences between the two methods exist, drying at $65^{\circ} \mathrm{C}$ should provide the more accurate results as TGA is typically the less accurate method because of sample drying as dry gas passes over the sample as the operator prepares to start the analysis.

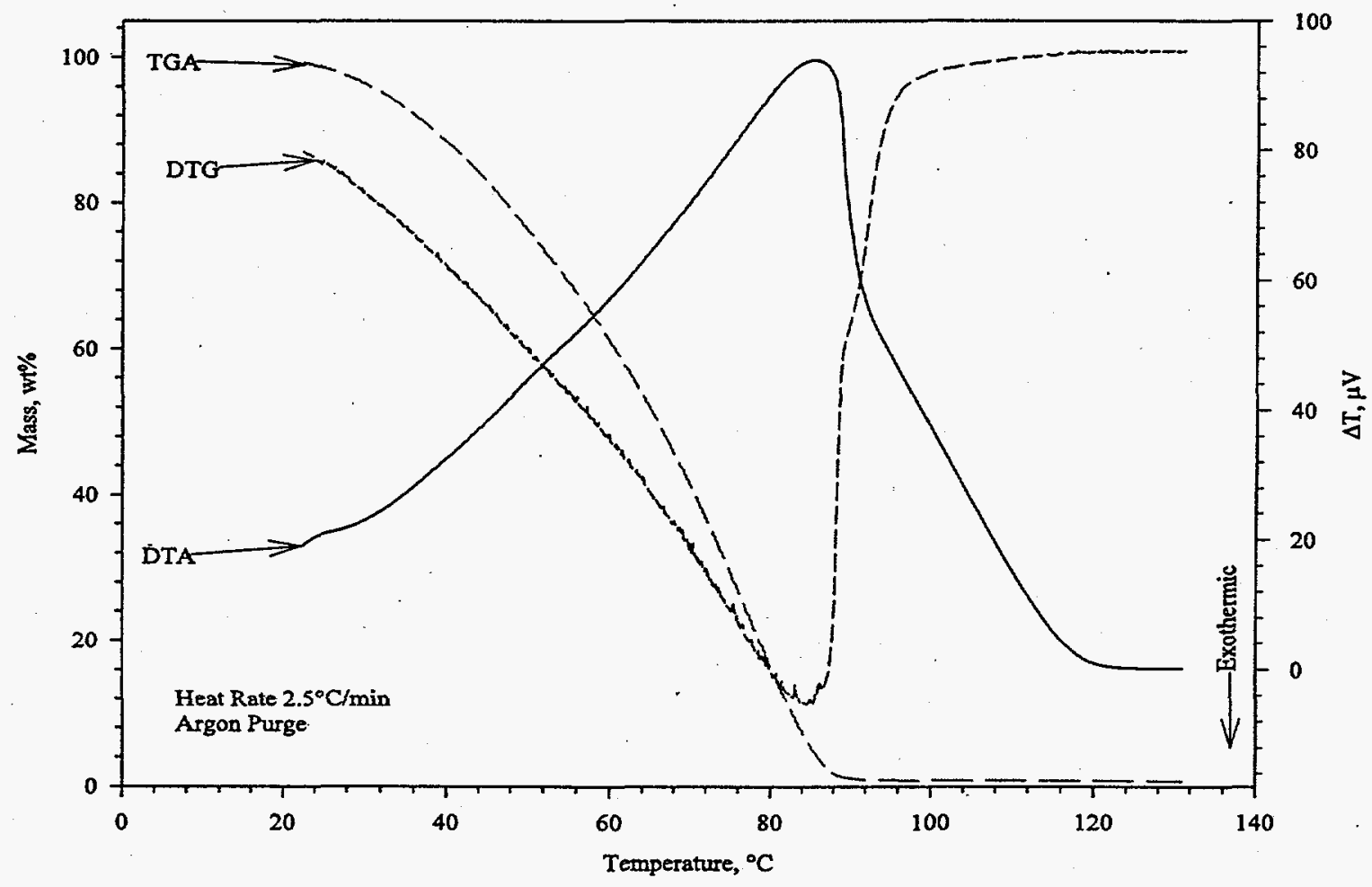

Figure 3.1. Thermal Behavior of Polywater ${ }^{\circ} \mathrm{G}$ Lubricant as Measured by Simultaneous TGA/DTA $\left(2.5^{\circ} \mathrm{C} / \mathrm{min}\right.$; argon purge $)$ 
The waste simulant 101SY/HEDTA, used in this study and earlier, was characterized and used by S. A Bryan in his gas generation studies (Bryan et al. 1992; Bryan and Pederson 1994). This simulant was a dried alkaline mixture of inorganic salts combined with about $7 \mathrm{wt} \% \mathrm{Na}_{3} \mathrm{HEDTA}$ ( $2 \mathrm{wt} \%$ TOC), having the nominal dry composition shown in Table 3.1. It is probable that reactions occurred between the different ingredients as the simulants were prepared to form a mixture composed of the added ingredients, transition metal and HEDTA complexes, and hydrous transition metal oxides. The major inorganics in the simulated waste were sodium nitrate, sodium nitrite, sodium aluminate, sodium phosphate, and sodium hydroxide. Although recent analyses by Campbell et al. (1994) and studies by Delegard (1987) and Camaioni et al. $(1994 ; 1995)$ indicate that HEDTA originally present in 101SY waste has degraded to a wide variety of organic species, we chose HEDTA to represent the organic waste constituents since it was originally present in the waste and to provide consistency with our earlier studies to assess the chemical compatibility of pump oil and $101 \mathrm{SY}$ waste. We dried our simulant at $50^{\circ} \mathrm{C}$ using the building vacuum of about 120 torr for 2 to 3 weeks and ground it using a mortar and pestle to provide a high-surface-area material to enhance reactivity.

Table 3.1. Recipe-Based Dry Basis Composition of Simulated 101SY Waste Containing $2 \mathrm{wt} \%$ TOC as $\mathrm{Na}_{3}$ HEDTA (Formulation SY1-SIM-92A [Bryan and Pederson 1994])

\begin{tabular}{|c|c|}
\hline Component & Weight \% \\
\hline $\mathrm{Na}_{3}$ HEDTA & 7.22 \\
\hline $\mathrm{NaCl}$ & 2.85 \\
\hline $\mathrm{Na}_{3} \mathrm{PO}_{4} * 12 \mathrm{H}_{2} \mathrm{O}$ & 6.31 \\
\hline $\mathrm{NaNO}_{2}$ & 25.26 \\
\hline $\mathrm{NaNO}_{3}$ & 17.33 \\
\hline $\mathrm{Na}_{2} \mathrm{CO}_{3}$ & 3.92 \\
\hline $\mathrm{NaF}$ & 0.39 \\
\hline $\mathrm{Na}_{2} \mathrm{SO}_{4}$ & 0.42 \\
\hline $\mathrm{CaCl}_{2}$ & 0.09 \\
\hline $\mathrm{KCl}$ & 1.0 \\
\hline $\mathrm{Cr}\left(\mathrm{NO}_{3}\right)_{3} * 9 \mathrm{H}_{2} \mathrm{O}$ & 3.89 \\
\hline $\mathrm{Cu}\left(\mathrm{NO}_{3}\right)_{2} * 2.5 \mathrm{H}_{2} \mathrm{O}$ & $5 e-03$ \\
\hline $\mathrm{Fe}\left(\mathrm{NO}_{3}\right) * 9 \mathrm{H}_{2} \mathrm{O}$ & 0.28 \\
\hline $\mathrm{Ni}\left(\mathrm{NO}_{3}\right) * 6 \mathrm{H}_{2} \mathrm{O}$ & 0.06 \\
\hline $\mathrm{NaOH}$ & 9.09 \\
\hline $\mathrm{NaAlO}_{2} * 0.21 \mathrm{NaOH} * 1.33 \mathrm{H}_{2} \mathrm{O}$ & 21.86 \\
\hline Total & 100 \\
\hline
\end{tabular}


Although the bulk of the actual waste stored in 101SY is about 35 wt\% water (Herting et al. 1992a; Herting et al. 1992b) and the crust is 20 to $40 \mathrm{wt} \%$ water (Reynolds 1992), we used dried materials to provide the most reactive mixtures because the waste and lubricant mixture might dry during or after the VDTT removal operation. Burger (1995) and Fauske et al. (1995) found that water will limit the reactivity of the organic and nitrate and/or nitrite reactions relative to the dried waste used in this study. Fauske et al. found that mixtures of organics, nitrate, and nitrite (4:1 mass ratio nitrate:nitrite) containing over $20 \mathrm{wt} \%$ water would not support a propagating reaction and that the capability of these mixtures containing $<20 \mathrm{wt} \%$ water to support a propagating reaction depends on the water content and the organic content or the energetics of the mixture.

The $10 \mathrm{wt} \%$ lubricant mixture was prepared in one drying step while the $90 \mathrm{wt} \%$ mixture was prepared stepwise in an attempt to distribute the waste or the residue evenly throughout the mixture. To prepare the $10 \mathrm{wt} \%$ mixture, the lubricant was added to the dry 101SY/HEDTA simulant and was occasionally stirred as the mixture was dried at $65^{\circ} \mathrm{C}$. To prepare the $90 \mathrm{wt} \%$ lubricant residue mixture, portions of the lubricant were added to the dry simulated waste, mixed, and dried at $65^{\circ} \mathrm{C}$. The dried mixture was broken up using a spatula, and another portion of the required lubricant was added, mixed, and dried. This process was repeated until the required amount of lubricant to yield a $90 \mathrm{wt} \%$ residue mixture had been added. The final product mixtures were ground through a 40 -mesh sieve; the mixtures appeared visually to be homogenous. 


\subsection{Equipment}

Accelerating rate calorimetry was the thermoanalytical method used in this study to determine if exothermic reactions occur between Polywater ${ }^{\circledR} \mathrm{G}$ lubricant residue and the oxidants in 101SY waste. Since we include results from other studies using the thermoanalytical techniques DSC and TGA, this section provides a brief description of all of these methods and how they were used for the results presented.

\subsection{Accelerating Rate Calorimeter}

Adiabatic calorimetry, such as ARC, is one of the principal methodologies used by the chemical industry to evaluate chemical hazards (Sharkey et al. 1992; West 1993). Adiabatic calorimetry can 1) be used to provide more accurate onset temperatures than DSC or DTA (Fenlon 1984), 2) measure reaction enthalpy or energy resulting from an exothermic reaction, and 3) provide thermokinetic parameters. The ARC produces information relative to sample temperature, the sample's self-heating rate, and pressure data as a function of time. For a well-behaved system, this information can then be used to determine reaction enthalpy, reaction onset temperature, and kinetic parameters, such as the activation energy.

The Dow Chemical Company originally developed the ARC to provide time-temperature-pressure data to assess the thermal kinetic hazards for chemical reactions occurring at adiabatic conditions. In addition to its use for measuring thermal kinetic hazards, the ARC can be used to measure heats of reaction (Townsend and Tou 1980) and exothermic reaction onset temperatures (AICHE 1995).

The ARC is an adiabatic calorimeter used for screening reactive chemical systems (AICHE 1995). The instrument as-designed measures pressure within the sample container and the combined sample and container temperature. The ARC can be used to determine reaction onset temperatures and to calculate reaction energetics and kinetic parameters.

Fenlon (1984) reported that Eastman Kodak used the ARC-measured onset temperature as a rule-ofthumb guide for assessing the thermal hazard for a batch chemical manufacturing process. Using this rule-of-thumb, if the normal process operating temperature or temperature that would occur due to a process upset is more than $50^{\circ} \mathrm{C}$ less than the ARC-measured onset temperature, and if the maximum process temperature is held for only a short time, then the thermal hazard would be low. If the maximum operating temperature is closer to the ARC-measured onset temperature than $50^{\circ} \mathrm{C}$, or if the maximum temperature is maintained for a significant period of time, then an isothermal ARC aging test would be performed. The AICHE (1995) notes that factors other than onset temperature are important and must be considered to complete the thermal hazard evaluation. Factors requiring consideration include total reaction enthalpy, reaction kinetics, and other materials that can serve as heat absorbers (water in the Hanford organic-bearing wastes) (AICHE 1995). 
In the ARC operation, a sample and its container are maintained in an adiabatic condition once an exothermic reaction is detected. As shown in the schematic presented in Figure 4.1, a spherical sample container, which is typically titanium, stainless steel, or Hastalloy, is mounted inside a nickel-plated copper jacket and attached to a pressure transducer via a $0.3175-\mathrm{cm}$ (1/8-inch) stainless steel tube and a Swagelock ${ }^{\oplus}$ fitting. The jacket is composed of three zones, top, side, and base. These are individually heated and controlled by Nisil/Nicrosil type $\mathrm{N}$ thermocouples, which are cemented on the inside surface of the jacket. The same type of thermocouple is clamped directly on the outside surface of the sample container. All the thermocouples are referenced to the ice point, which is designed to be stable to within $0.01^{\circ} \mathrm{C}$. Diabatic conditions are achieved by maintaining a null temperature difference across the bomb and jacket. Furthermore, because a mismatch between the thermocouples attached to the bomb and jacket can cause a drift from adiabatic conditions, the drift must be corrected. To prevent this mismatch, the instrument is calibrated at $50^{\circ} \mathrm{C}$ intervals to determine the offset voltage that must be applied by the instrument during an analysis to ensure correspondence between the sample and jacket thermocouples. These corrections will maintain adiabatic conditions at any temperature.

During an exothermic reaction, the temperature differences of the bomb and three zones of the jacket are digitally controlled by employing commonly used proportional, differential, and integral control algorithms until the reaction is complete. The pressure of the system can be monitored up to $1.7 \mathrm{E} 04 \mathrm{kPa}$ ( $2500 \mathrm{psi}$ ) by a pressure transducer. A relief valve is installed to protect the transducer at pressures above $1.7 \mathrm{E} 04 \mathrm{kPa}$. The entire calorimeter is placed in an insulated aluminum canister and mounted inside a rugged steel containment shell.

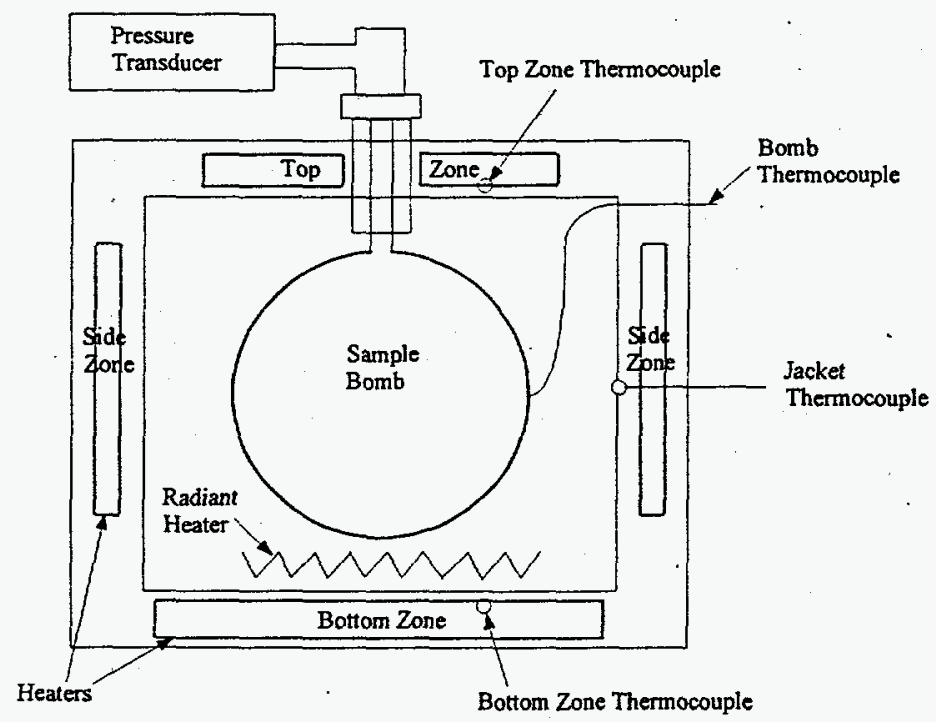

Figure 4.1. Schematic of Accelerating Rate Calorimeter (Townsend and Tou 1980) 
The ARC incorporates a heat-wait-search operational logic during an experiment. Initially, the reaction chamber is heated to a desired starting temperature and held at that temperature for an operatorselected period of time (wait time) to allow thermal equilibrium to be achieved. The instrument then searches for heat production using an operator-selected, self-heating rate criteria (preset rate) for an operator-elected period of time (search time). If the self-heating rate is less than the detection criterion, the instrument will automatically increase the temperature by an operator-selected amount (heat step) and execute another heat-wait-search sequence until the instrument detects a self-heating rate greater than the preset rate. When that condition is met, the ARC is maintained at adiabatic conditions until the experiment is completed.

The instrument is capable of maintaining adiabatic conditions (i.e., maintaining equal sample and calorimeter temperatures) during an exothermic event to within $0.1^{\circ} \mathrm{C}$ with sample self-heat rates up to $15^{\circ} \mathrm{C} / \mathrm{min}$. The instrument identifies an exothermic event using a user-established criterion of down to $0.01^{\circ} \mathrm{C} / \mathrm{min}\left(14^{\circ} \mathrm{C} /\right.$ day) on 0.1 - to 10 -gram samples such as liquid, solid, gas, slurry, and mixtures. The instrument has operating temperatures ranging from ambient up to $425^{\circ} \mathrm{C}$ and pressures up to $1.4 \mathrm{E} 04 \mathrm{kPa}$ ( $2000 \mathrm{psi}$ ) (pressure accuracy of $0.1 \%$ of full-scale). The ARC produces information about temperature, self-heating rate, and presssure data as a function of time, which can then be used to determine reaction onset temperature and calculate reaction enthalpy and kinetic parameters, such as the activation energy. The as-measured onset temperature for a self-sustaining reaction will be higher than under true adiabatic conditions because the sample must produce heat at a sufficient rate to heat both itself and the container to the detection criterion rate.

In the current experiments, duplicate analyses of 3-g samples were contained in new 10-mL titanium bombs weighing approximately 6.2 grams each. Before an experiment was initiated, argon was blown into the 6-mm cylindrical mouth briefly, and then the sample bombs were pressure-tested with argon to ensure the integrity of the system. The experiments were conducted with $10^{\circ} \mathrm{C}$ heat steps. The wait-andsearch times were 10 and 3 minutes, respectively. The exothermic reaction detection criterion used was $0.02^{\circ} \mathrm{C} / \mathrm{min}\left(28^{\circ} \mathrm{C} /\right.$ day), which corresponds to about $0.06 \mathrm{~J} / \mathrm{min} / \mathrm{g}$ sample for a $3-\mathrm{g}$ sample such as used for this study.

The instrument was calibrated according to the manufacturer's procedure described earlier, and the calibration was confirmed by comparing the reported temperature with the temperature measured inside the sample holder by a calibrated thermocouple and digital thermometer system; the thermocouple and thermometer were calibrated by PNNL's Craft Services using standards traceable to the National Institute of Standard Technology (NIST). 


\subsection{Differential Scanning Calorimetry and Differential Thermal Analysis}

Differential scanning calorimetry and DTA are recommended techniques for screening a chemical system for exothermic behavior and for providing preliminary information on reaction onset temperature and heat of reaction (Sharkey et al. 1992; West 1993; Hoppe 1992). The two instruments have similar applications since both observe heat production or absorption as the temperature of a small ( 2 to $100 \mathrm{mg}$ ) sample increased at a known, controlled, and constant rate.

Differential scanning calorimetry and DTA are two effective methods for observing reactions that produce or require heat. The DSC measures and reports enthalpy changes while the DTA measures temperature differences between a sample and an inert reference material, typically alumina; the DTA can provide enthalpy changes by correlating the temperature difference with known calorimetric standards over the temperature range used. Both instruments can be operated either in a temperature-scanning mode (normal operation) or isothermally. For this work, we used both instruments in their temperaturescanning mode by heating a small sample ( 2 to $20 \mathrm{mg}$ for the DSC and 10 to $100 \mathrm{mg}$ for the DTA) at a known and constant rates of 2.5 or $5^{\circ} \mathrm{C} / \mathrm{min}$ in a constantly flowing argon gas purge. By performing a series of analyses at several different heating rates or operating the instruments isothermally, kinetic parameters can be measured.

The DSC used to obtain the results provided in this report operates using a power-compensation design, while the DTA used was a heat-flux instrument. The power compensation DSC's theory of operation is based on the "null-balance" DSC principle in which energy absorbed or evolved by the sample is compensated by adding an equivalent amount of electrical energy to the sample or reference heater. A platinum resistance heater and thermometers are used in this DSC to measure temperature and energy. The continuous and automatic adjustment of the heater power $(\mathrm{mW})$, which is necessary to keep the sample holder temperature identical to that of the reference holder, provides a varying electrical signal equivalent to the varying thermal behavior of the sample. By integrating the area under an observed peak, the instrument provides true electrical energy measurements of an event (J). The DTA is less complicated in design with the sample and reference heated by a single heating source and the temperature difference between the two recorded as a function of temperature or time. Enthalpy can be obtained from the DTA analysis by calibrating the instrument's response using multiple enthalpy standards over the temperature range of interest and converting the integrated temperature differences to energy units.

Interpreting the DSC and DTA curves is often complicated by a changing baseline due to changing heat capacities or simultaneous reactions. Normally, to identify the nature of the thermal behavior, whether it is endothermic (requires heat to occur) or exothermic (produces heat), the analyst identifies deviations or changes from the immediately preceding curve or the null or zero point. In a well-behaved system, anything less than 0 would be exothermic. Typically nitrate and nitrite oxidations of organics are complex reactions (Scheele et al. 1995) and are therefore not well-behaved, so in the figures, exothermicity is indicated by a downward change relative to the immediately preceding data. Often TGA is used to provide additional information on the nature of the DSC- or DTA-observed reactions; our DTA is part of a simultaneous DTA and TGA instrument that observes enthalpy changes and mass changes on the same sample. 
The DSC and DTA analyses reported here were conducted in duplicate under nonisothermal conditions $\left(5^{\circ} \mathrm{C} / \mathrm{min}\right)$ from ambient to the selected final temperature in flowing nitrogen or argon (approximately $30 \mathrm{~mL} / \mathrm{min}$ ). The sample sizes ranged from 3 to $50 \mathrm{mg}$. The DSC and TGA were temperature-calibrated using indium and zinc melting point standards; the indium standard was used for enthalpy calibration of the DSC. For the DSC and DTA, samples were encapsulated in aluminum sample containers; no reactions have been observed between aluminum pans and sodium nitrate and/or nitrite in other studies.

\subsection{Thermogravimetric Analysis}

Thermogravimetric analysis is similar and complementary to the DSC and DTA, only it measures mass changes as the temperature is increased at a known and constant rate. The typical sample size ranges from 3 to $50 \mathrm{mg}$, and the furnace chamber is purged with a flowing gas stream to remove gaseous products. In this system, the gases are carried to an infrared spectrophotometer for identification. Typically, the presentation of the mass-loss data includes the differential of the mass-loss curve (DTG), which should correspond to a DSC-observed event if a mass change occurs simultaneously with a reaction. If the sample undergoes a physical change, such as melting or a crystal change, a mass loss will not occur. The TGA can also be operated isothermally. We used two TGAs for the work presented in this report; the first is an independent instrument, and the second is a simultaneous DTA and TGA.

For any TGA results provided in this report, duplicate analyses were performed using 3- to 50-mg samples contained in an aluminum sample pan. The sample container and sample were then loaded onto the sample holder and heated from ambient to the final temperature at a rate of 2.5 or $5^{\circ} \mathrm{C} / \mathrm{min}$ in argon, flowing at a rate of approximately $100 \mathrm{~mL} / \mathrm{min}$. 


\subsection{Reactivity of Polywater ${ }^{\circledR}$ and Simulated 101SY/HEDTA}

This section presents the results of our ARC analyses to determine if dried Polywater ${ }^{\oplus}$ lubricant could react with 101SY waste during VDTT removal operations. These results include ARC analyses of the dried Polywater ${ }^{\oplus}$ lubricant and the 101SY/HEDTA simulant to provide a reference to allow interpretation of the ARC analyses of the 10 and $90 \mathrm{wt} \%$ lubricant residue and 101SY/HEDTA simulated waste mixtures. We have also included DSC, TGA, and ARC analyses of a $2 \mathrm{wt} \%$ TOC mixture of $\mathrm{Na}_{3}$ HEDTA and equimolar sodium nitrate and nitrite; DSC and TGA analyses of 101SY/HEDTA are also presented to illustrate that the 101SY waste will itself support self-sustaining exothermic reactions if heated above $200^{\circ} \mathrm{C}$ at adiabatic conditions.

\subsection{Thermal Behavior of Dried Polywater ${ }^{\circledR}$ Lubricant}

As illustrated in Figure 5.1, dried Polywater ${ }^{\oplus}$ lubricant does not exhibit any exothermic reactions that will support a self-sustaining exothermic reaction producing greater than $0.1 \mathrm{~J} / \mathrm{min} / \mathrm{g}$ below $200^{\circ} \mathrm{C}$. The lubricant's behavior is characterized principally by endothermic reactions, with the ARC only observing a positive heating rate near $190^{\circ} \mathrm{C}$ for one of the analyses, and that is below our criteria used to identify an exothermic reaction. The pressure data indicate that the lubricant is decomposing gradually as it is heated as would be suggested by the observed general endothermic behavior. The lack of a sharp increase in pressure during the observed endothermic event near $60^{\circ} \mathrm{C}$ suggests that the dried lubricant may melt near that temperature. The ARC analyses indicate that the decomposition of the dried lubricant should not be exothermic up to at least $190^{\circ} \mathrm{C}$.

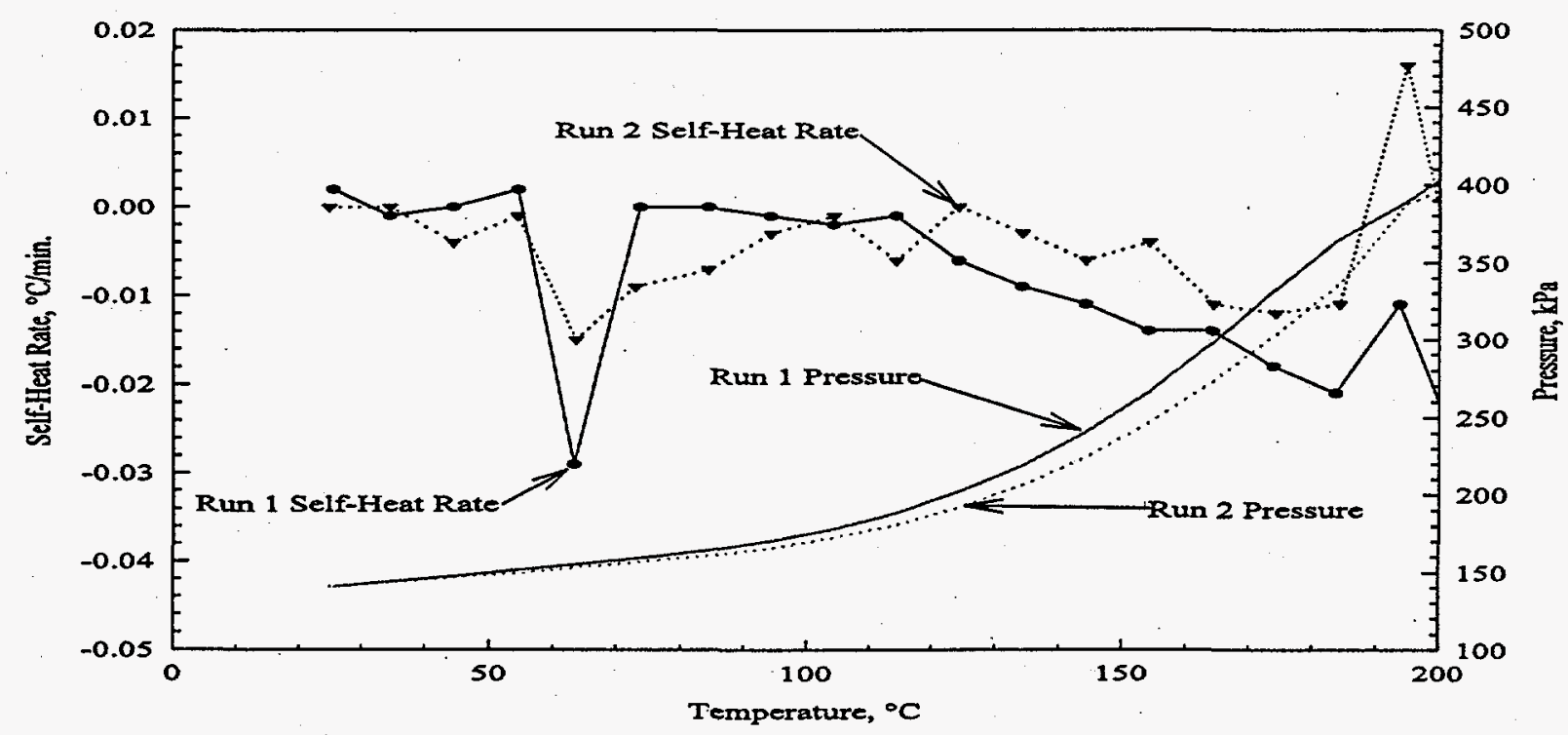

Figure 5.1. Thermal Behavior of Dried Polywater ${ }^{\circ}$ Lubricant as Measured by ARC 


\subsection{Thermal Reactivity of 101SY/HEDTA}

The thermal reactivity of the surrogate waste, $2 w t \%$ TOC as HEDTA and equimolar sodium nitrate and nitrite, and the 101SY/HEDTA simulated waste is needed as a basis for interpreting the results obtained for the mixtures of lubricant residue and 101SY/HEDTA. To provide this reference basis, DSC, TGA, and ARC analyses obtained by PNNL either for this study or in support of PNNL's Organic Tank Safety and Flammable Gas Projects are provided in this section.

No exothermic behavior should be observed up to $190^{\circ} \mathrm{C}$ for the two lubricant residue and simulated 101SY waste mixtures due to the 101SY/HEDTA waste simulant. This is based on the DSC-, TGA-, and ARC-observed behavior of the $\mathrm{Na}_{3} \mathrm{HEDTA}$ and equimolar sodium nitrate and nitrite mixture presented in Figure 5.2 (Scheele et al. 1995) and the DSC, TGA, and ARC results for 101SY/HEDTA simulant presented in Figures $5.3^{(\mathrm{a})}$ and 5.4.

The DSC observed (Figures 5.2 and 5.3) that below $190^{\circ} \mathrm{C}$, only endothermic reactions occur, probably because of loss of absorbed water, loss of waters of hydration, crystalline phase changes, and melting of the sodium nitrate and nitrite. The DSC analyses below $200^{\circ} \mathrm{C}$ are characterized by an endothermic peak beginning near $160^{\circ} \mathrm{C}$, which is characteristic of the nitrate and nitrite mixture (Scheele et al. 1995). The TGA analysis of the HEDTA and equimolar sodium nitrate and nitrite mixture indicates that this characteristic reaction has no associated mass loss; however, the TGA of the partially dried 101SY/HEDTA (Figure 5.3) and associated evolved gas analysis obtained by Bryan (unpublished) using infrared spectroscopy indicates that this reaction results in loss of water. In these unpublished infrared (IR) evolved gase analyses, Bryan observed only water in the evolved gases below $200^{\circ} \mathrm{C}$ with no HEDTA and nitrate/nitrite reaction product gases such as nitrous oxide or carbon dioxide, indicating that no reactions occur between HEDTA and the nitrate and/or nitrite in the simulant below $200^{\circ} \mathrm{C}$.

Consistent with the DSC analyses, the ARC, as shown in Figures 5.2 and 5.4, observed no exothermic reactions for either the HEDTA and nitrate/nitrite mixture or 101SY/HEDTA below $190^{\circ} \mathrm{C}$, although the results presented in Figure 5.2 indicate that a self-sustaining reaction between HEDTA and nitrate and/or nitrite begins between 190 and $200^{\circ} \mathrm{C}$. No exothermic reactions exceeding the $0.02^{\circ} \mathrm{C} / \mathrm{min}(0.06 \mathrm{~J} / \mathrm{min} / \mathrm{g}$ sample $)$ detection criteria were observed for both the surrogate and simulated wastes; in fact, the ARC saw no exothermic reactions exceeding $0.01^{\circ} \mathrm{C} / \mathrm{min}$ $(0.03 \mathrm{~J} / \mathrm{min} / \mathrm{g})$. The ARC analyses of 101SY/HEDTA presented in Figure 5.4 are characterized by endotherms with maximum cooling rates near $160^{\circ} \mathrm{C}$. The difference in the pressures between the two analyses presented in Figure 5.4 is due to different initial pressurization with Ar.

During the ARC analysis, the absence of significant pressure increases that would be predicted based on Bryan's TGA (Figure 5.3) is likely due to differences in the drying method between our 101SY/HEDTA and Bryan's preparation. SA Bryan dried his 101SY/HEDTA at $50^{\circ} \mathrm{C}$ under a vacuum for 2 to 3 days compared to our 2 to 3 weeks; Bryan did not dry the simulant to a stable

(a) Provided by the courtesy of SA Bryan of PNNL and the PNNL Flammable Gas Project. 

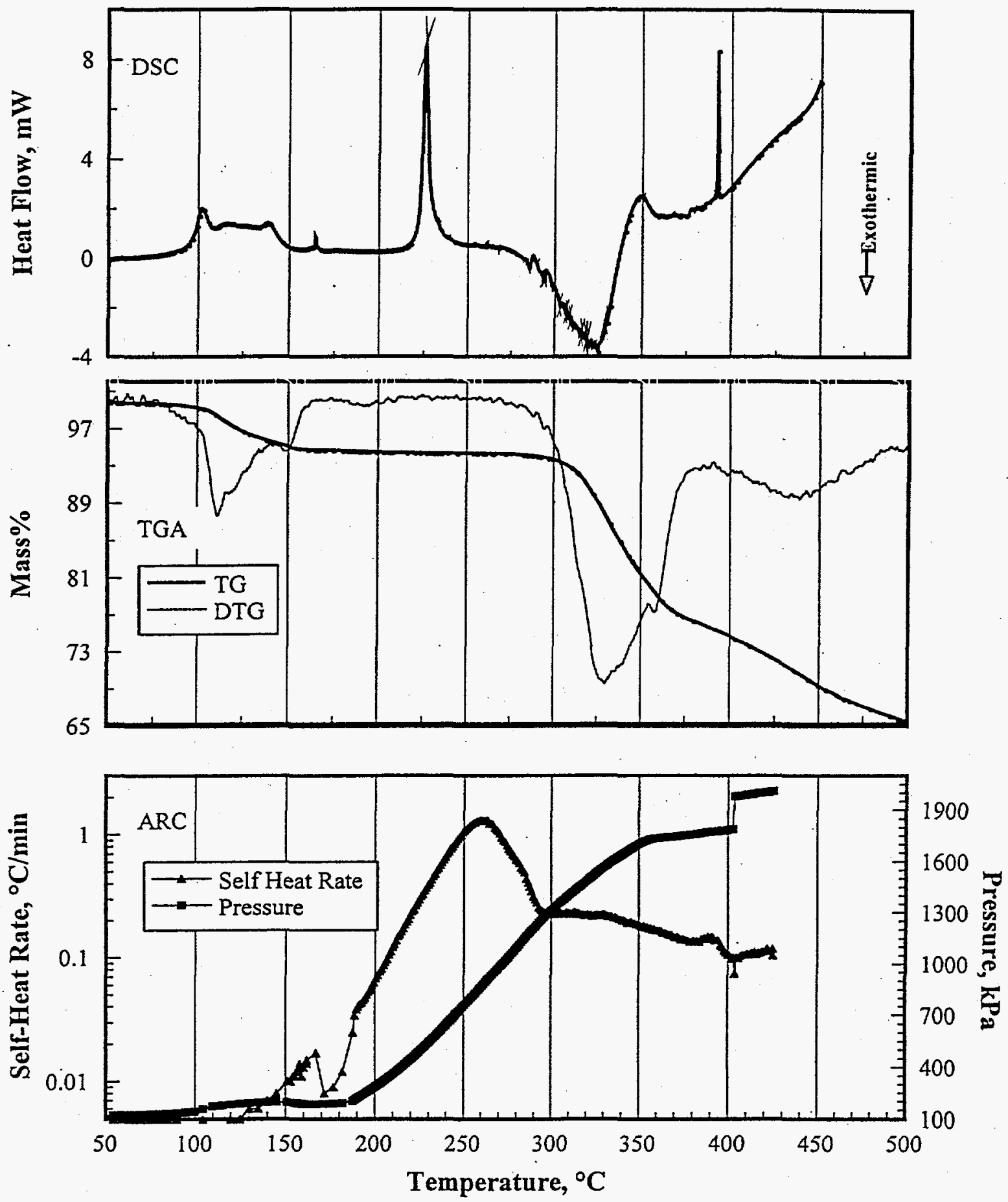

Figure 5.2. Thermal Behavior of a 2 wt\% Total Organic Carbon Mixture of $\mathrm{Na}_{3}$ and Equimolar Sodium Nitrate and Nitrite as Measured by DSC, TGA, and ARC (Scheele et al. 1995) 


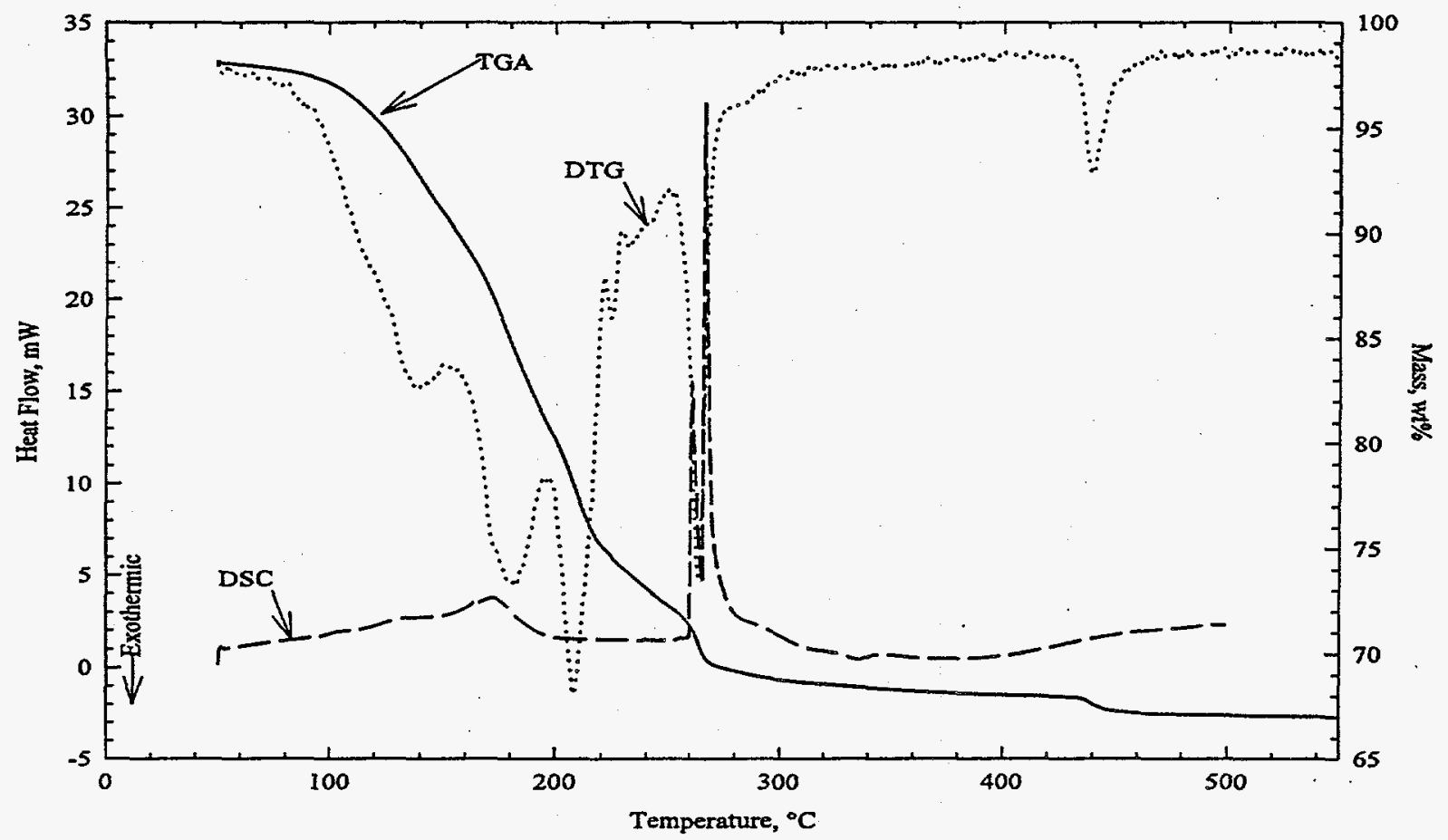

Figure 5.3. Thermal Behavior of 101SY/HEDTA Simulated Waste as Measured by DSC and TGA/DTG (Provided by SA Bryan of PNNL)

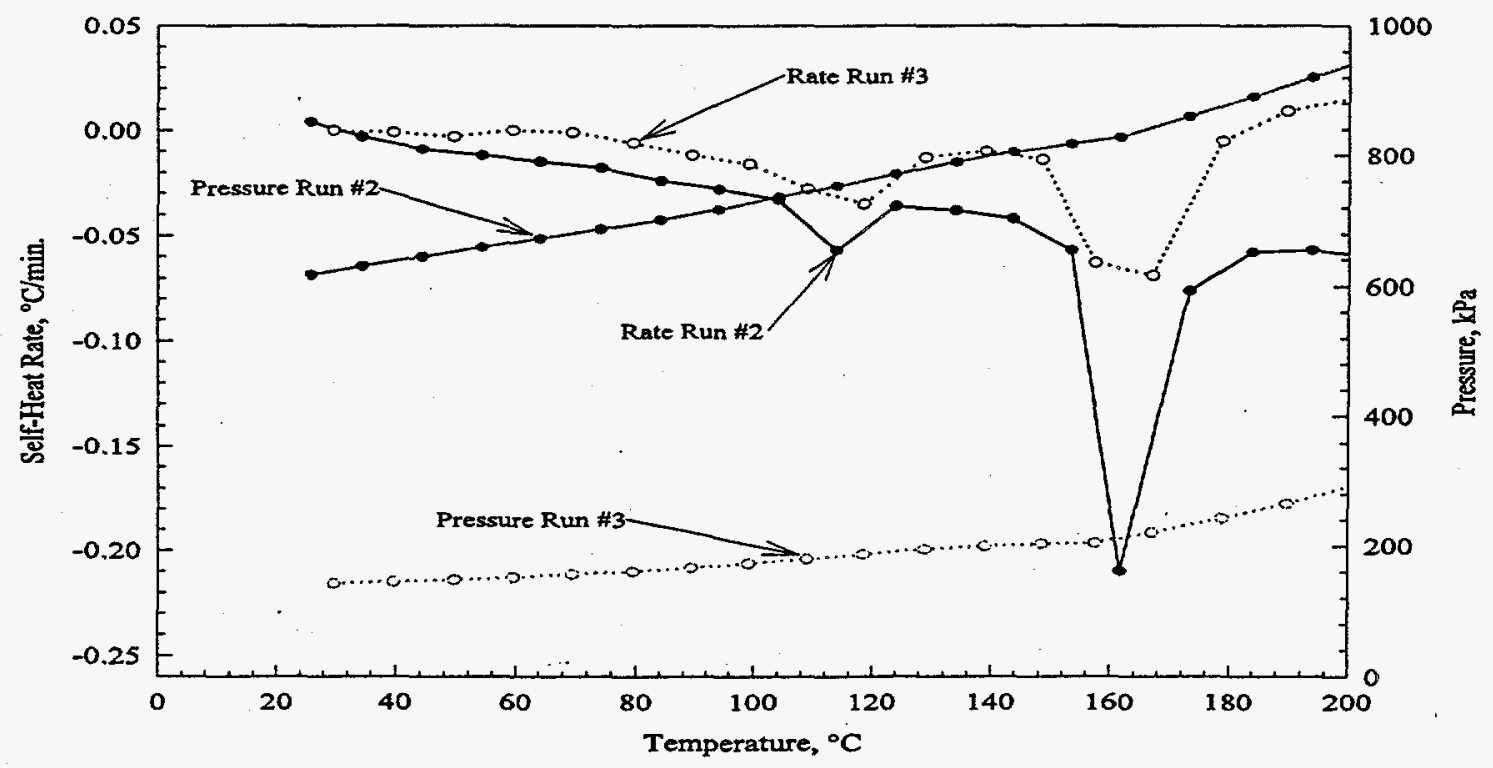

Figure 5.4. Thermal Behavior of 101SY/HEDTA ( 2 wt\% TOC) Simulated Waste as Measured by ARC to $200^{\circ} \mathrm{C}$ 
mass before removing it from the vacuum drying oven. The substantial water content found in Bryan's dried simulant illustrates how strongly this simulant retains water and suggests that actual 101SY waste should be slow to dry during the VDTT removal operation; wastes containing substantial amounts of sodium hydroxide can retain substantial amounts of water (Scheele, Bredt, and Sell 1996; Barney 1976; Fauske et al. 1995).

With respect to the reported thermal sensitivity of waste stored in 101SY, the results that Herting et al. (1992a; 1992b) observed in their thermal analyses of waste stored in 101SY are similar to those obtained in our studies for the HEDTA and sodium nitrate/nitrite surrogate waste and the 101SY/HEDTA simulant, although there is an indication of increased thermal sensitivity (about a $20^{\circ} \mathrm{C}$ lower onset temperature) of the actual waste relative to the surrogate and simulated wastes that we used. The DSC analyses provided by Herting et al. indicate, as did the DSC analyses (Figures 5.2 and 5.3) that below $190^{\circ} \mathrm{C}$, only endothermic reactions occur. They report that a series of at least two exothermic reactions begin above $190^{\circ} \mathrm{C}$ in their Window $\mathrm{C}$ sample analyses (1992a). Using Fauske and Associates' Reactive System Screening Tool (RSST), a sensitive calorimetric method (like the ARC) for observing exothermic reactions (AICHE 1995), Herting et al. (1992b) found that dried waste from 101SY begins a self-heating exothermic reaction below $170^{\circ} \mathrm{C}$; Herting et al. suggest that the reaction begins during the melting of the oxidant and inert salt mixture below $170^{\circ} \mathrm{C}$.

\subsection{Thermal Reactivity of Mixtures of Polywater ${ }^{\circledR}$ Residue and 101SY/HEDTA}

The ARC analyses of the $10 \mathrm{wt} \%$ Polywater $^{\star}$ residue and 101SY/HEDTA simulated waste (Figure 5.5) indicate that no exothermic reactions capable of producing $>0.1 \mathrm{~J} / \mathrm{min} / \mathrm{g}$ mixture occur between the lubricant residue and the 101SY/HEDTA simulant below $190^{\circ} \mathrm{C}$. The ARC self-heating results (Figure 5.5) indicate that only endothermic reactions occur for this mixture below $200^{\circ} \mathrm{C}$.

Comparing the reaction profile of the $10 \mathrm{wt} \%$ lubricant residue mixture with the reaction behaviors of the lubricant residue (Figure 5.1) and 101SY/HEDTA (Figure 5.4) indicates that the observed endothermic reactions are due to the simulant with little contribution from the $10 \mathrm{wt} \%$ lubricant residue. The reaction observed with a maximum cooling rate near $150^{\circ} \mathrm{C}$ may correspond to the endothermic reaction observed by Scheele et al. (1995) for a mixture of sodium nitrate and nitrite. The change in slope for the pressure results observed beginning between 140 and $150^{\circ} \mathrm{C}$ suggests that gas is released during this endothermic reaction. Additional analyses such as TGA and real-time evolved gas analysis would be required to identify the nature and source of this observed reaction, however, because the reaction was endothermic, these analyses were not performed.

Extrapolating the results of this study to the planned removal of the VDTTs with the subsequent release of the lubricant on top of and into waste stored in 101SY indicates that the introduction of $10 \mathrm{wt} \%$ lubricant residue into $101 \mathrm{SY}$ waste should cause no significant exothermic reactions at the expected thermal conditions of $60^{\circ} \mathrm{C}$. 


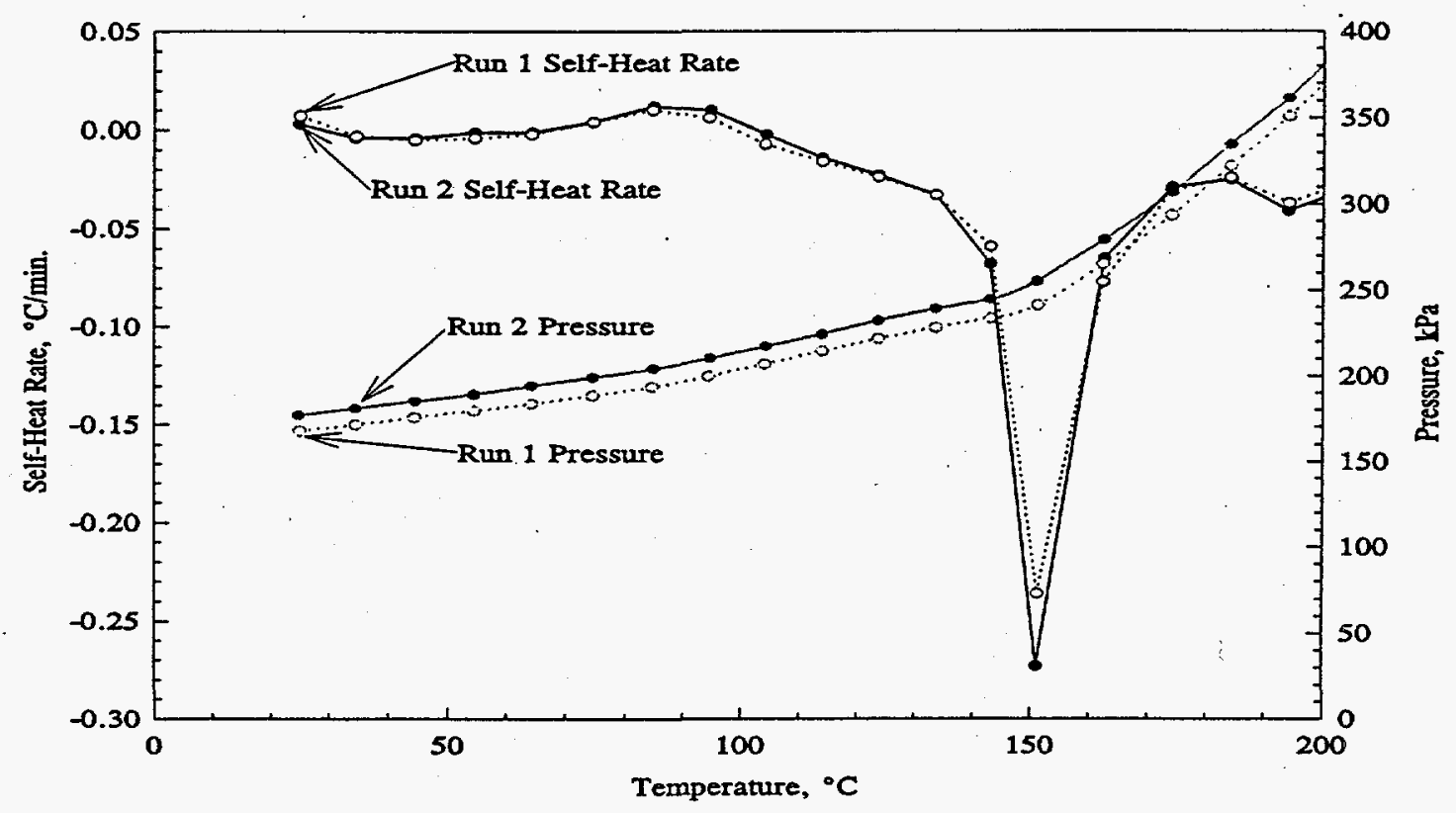

Figure 5.5. Thermal Behavior as Measured by ARC of a $10 \mathrm{wt} \%$ Dried Polywater ${ }^{\circledR}$ Lubricant Mixed with Simulated 101-SY Waste Containing 2 wt\% TOC as $\mathrm{Na}_{3} \mathrm{HEDTA}$

The ARC analyses of the $90 \mathrm{wt} \%$ Polywater $^{\circ} \mathrm{G}$ residue and 101SY/HEDTA mixture (Figure 5.6) indicate that no exothermic reactions capable of producing $>0.1 \mathrm{~J} / \mathrm{min} / \mathrm{g}$ mixture occurred between the residue and the oxidants in the simulant. As with the $10 \mathrm{wt} \%$ residue mixture, only endothermic reactions were observed for the $90 \mathrm{wt} \%$ mixture.

The ARC results for the $90 \mathrm{wt} \%$ lubricant residue mixture are characterized by the characteristic endotherm observed for sodium nitrate and nitrite mixtures to a lesser extent than the $10 \mathrm{wt} \%$ lubricant residue mixture. The cooling rates observed for the $90 \mathrm{wt} \%$ residue mixture were significantly slower than for the $10 \mathrm{wt} \%$ mixture. These results would be expected because of the lower 101SY/HEDTA concentration.

The ARC pressure results begin to show deviation from linearity (predicted for an ideal gas) near $80^{\circ} \mathrm{C}$. This deviation from the ideal at a lower temperature than observed for the $10 \mathrm{wt} \%$ residue mixture (Figure 5.5) and comparison with the behavior of the lubricant residue (Figure 5.1) is consistent with the increased lubricant residue concentration. The apparent difference between the TGA-observed decomposition (Figure 3.1) and the ARC-pressure results may be due to the longer time used in the ARC experiments. 


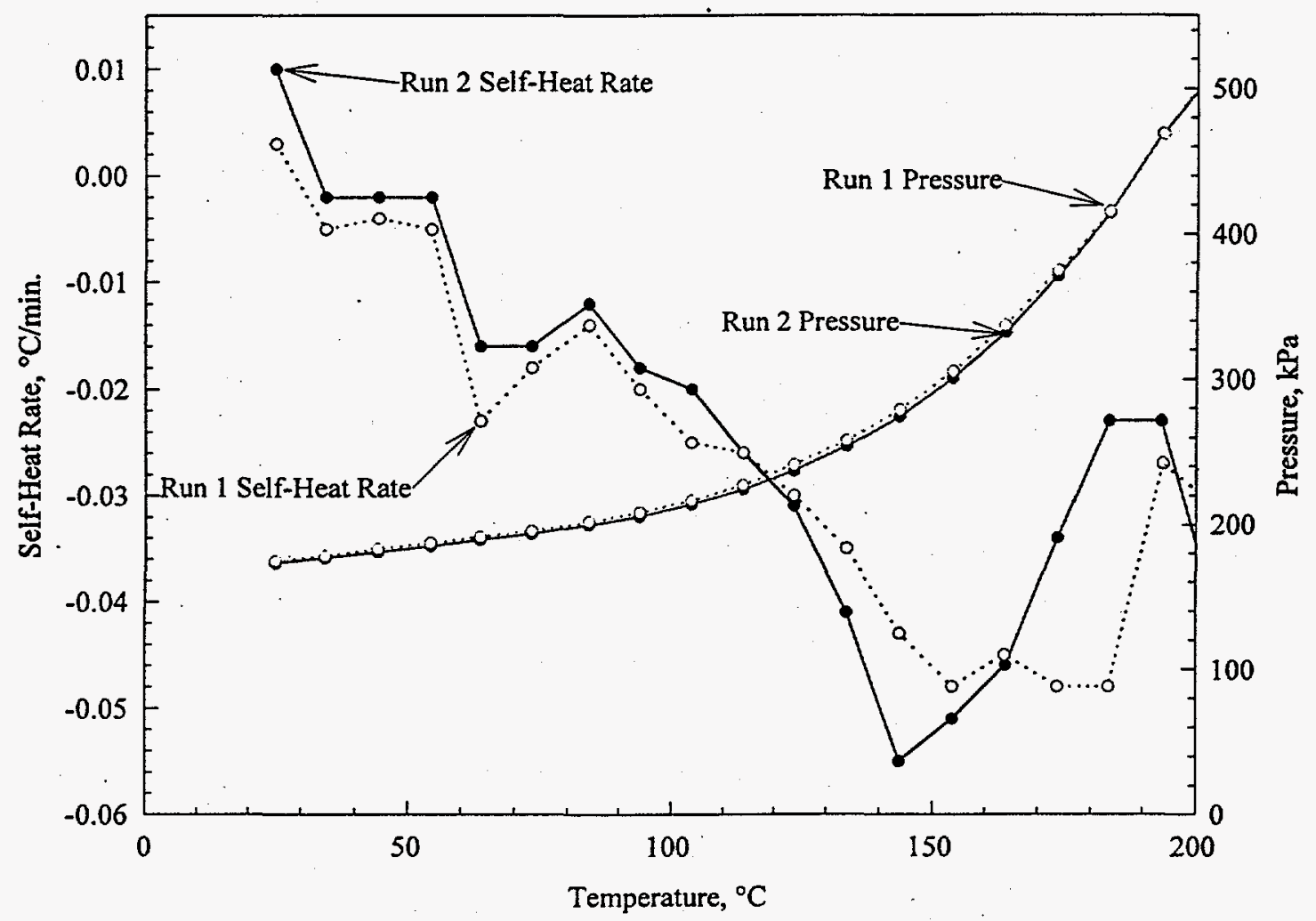

Figure 5.6. Thermal Behavior of a 90 wt \% Polywater $G$ Lubricant Residue and 101SY/HEDTA Simulated Waste as Measured by ARC

In summary, the results of the ARC analyses of dried 10 and $90 \mathrm{wt} \%$ mixtures of Polywater $\mathrm{G}$ residue and simulated $101 \mathrm{SY}$ waste indicate that the lubricant residue flushed from the VDTT should be chemically compatible with the oxidants in 101SY waste with no significant heatproducing reactions occurring between the lubricant residue that is suspected of being in the VDTTs and the 101SY waste at the expected thermal conditions of $60^{\circ} \mathrm{C}$. 


\subsection{References}

American Institute of Chemical Engineers (AICHE). 1995. Guidelines for Chemical Reactivity Evaluation and Application to Process Design. Center for Chemical Process Safety, New York.

Barney, G. S. 1976. Vapor-Liquid-Solid Phase Equilibria of Radioactive Sodium Salt Wastes at Hanford. ARH-ST-113, Atlantic Richfield Hanford Company, Richland, Washington.

Bryan, S. A., L. R. Pederson, J. L. Ryan, R. D. Scheele, and J. M. Tingey. 1992. Slurry Growth, Gas Retention, and Flammable Gas Generation by Hanford Radioactive Waste Tanks: Synthetic Waste Studies. PNL-8169, Pacific Northwest Laboratory, Richland, Washington.

Bryan, S. A., L. R. Pederson. 1994. Composition, Preparation, and Gas Generation Results from Simulated Wastes of Tank 241-SY-101. PNL-10075. Pacific Northwest Laboratory, Richland, Washington.

Burger, L. L. 1995. Calculation of Reaction Energies and Adiabatic Temperatures for Waste Tank Reactions. PNL-8557 Rev. 1, Pacific Northwest Laboratory, Richland, Washington.

Camaioni, D. M., W. D. Samuels, B. D. Lenihan, S. A. Clauss, K. L. Wahl, and J. A. Campbell. 1994. Organic Tanks Safety Program - Waste Aging Studies. PNL-10161, Pacific Northwest Laboratory, Richland, Washington.

Camaioni, D. M., W. D. Samuels, S. A. Clauss, B. D. Lenihan, K. L. Wahl, J. A. Campbell, and W. J. Shaw. 1995. Organic Tanks Safety Program - FY95 Waste Aging Studies. PNL-10794, Pacific Northwest Laboratory, Richland, Washington.

Campbell, J. A., R. W. Stromatt, M. R. Smith, D. W. Koppenaal, R. M. Bean, T. E. Jones, D. M. Strachan, and H. Babad. 1994. "Organic Analysis at the Hanford Nuclear Site." Anal. Chem., Vol. 66, No. 24, 1208A-1215A.

Delegard, C. 1980. Laboratory Studies of Complexed Waste Slurry Volume Growth in Tank 241SY-101. RHO-LD-124, Rockwell International, Richland, Washington.

Delegard, H. C. 1987. Identities of HEDTA and Glycolate Degradation Products in Simulated Hanford High-Level Waste. RHỌ-RE-ST-55P, Rockwell Hanford Operations, Richland, Washington.

Fauske, H. K., M. Epstein, D. R. Dickenson, R. J. Cash, and J. E. Meacham. 1995. The Contact Temperature Ignition (CTI) Criteria for Propagating Chemical Reactions Including the Effect of Moisture and Application to Hanford Waste. WHC-SD-WM-ER-496, Rev. 0, Westinghouse Hanford Company, Richland, Washington. 
Fenlon, W. J. 1984. "A Comparison of ARC and Other Thermal Stability Test Methods." Plant/Op Prog, 3(4), 197-202.

Herting, D. L., D. B. Bechtold, B. A. Crawford, T. L. Welsh, and L. Jensen. 1992a. Laboratory Characterization of Samples Taken in May 1991 from Hanford Waste Tank 241-SY-101. WHC-SDWM-DTR-024 Rev. 0, Westinghouse Hanford Company, Richland, Washington.

Herting, D. L., D. B. Bechtold, B. E. Hey, B. D. Keele, L. Jensen, and T. L. Welsh. 1992 b. Laboratory Characterization of Samples Taken in December 1991 (Window E) from Hanford Waste Tank 241-SY-101. WHC-SD-WM-DTR-026 Rev. 0, Westinghouse Hanford Company, Richland, Washington.

Hoppe, T. 1992. "Use Reaction Calorimetry for Safer Process Designs." Chem Eng Prog, 88(9), 70-74.

Reynolds, D. A. 1992. Tank 101-SY Window C Core Sample Results and Interpretation. WHCEP-0589, Westinghouse Hanford Company, Richland, Washington.

Scheele, R. D., J. L. Sobolik, R. L. Sell, and L. L. Burger. 1995. Organic Tank Safety Project: Preliminary Results of Energetics and Thermal Behavior Studies of Model Organic Nitrate and/or Nitrite Mixtures and a Simulated Organic Waste. PNL-10213, Pacific Northwest Laboratory, Richland, Washington.

Scheele, R. D., P. R. Bredt, and R. L. Sell. 1996. Organic Tank Safety Project: Development of a Method to Measure the Equilibrium Water Content of Hanford Organic Tank Wastes and Demonstration of Method on Actual Waste. PNNL-11227, Pacific Northwest National Laboratory, Richland, Washington.

Sharkey, J. J., R. S. Cutro, W. J. Fraser, and G. T. Wildman. 1992. "Plant Safety Testing Program for Reducing Risks Associated with Large Scale Chemical Manufacturing Operations." Plant/Op Prog, 11(4), 238:246.

Townsend, D. I., and J. C. Tou. 1980. "Thermal Evaluation by an Accelerating Rate Calorimeter." Thermochemica Acta 37, (1980) 1:30.

West, A. S. 1993. "Chemical Reactivity Evaluation: The CCPS Program." Process Safety Progress 12(1) 55:60. 


\section{Appendix A}

\section{POLYWATER ${ }^{\circledR}$ Lubricant G Material Safety Data Sheet}


American

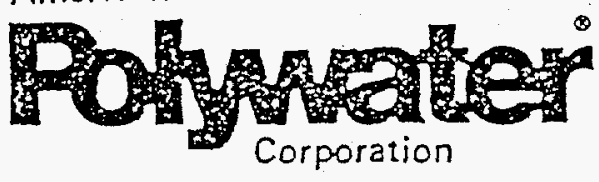

MSDS 15321

11222 boin Sireet Norn

P.O. Eex 53

Stillwater, Minnesota 55082

Telephons: $612-430-2270$.

\section{MATERIAL SAFETY DATA SHEET}

Date Prepared: Warch 19, 1987

\section{SECTION I. GENERAI}

Product Nace: POIYHATER ${ }^{\circ}$ Lubricant $G$

Menufacturer: American Polywater Corporation

11222 - 60ti Street North

?.0. $30 \times 53$

Stillwater, Nit 55082 U.S.A.

Emergency Numbers: Telephone: (612) 430-2270

Telex: 551647 (Aser Polywacer)

Chemical Description \& Synonyas: Polymer/Water/Isopropanol Solurion

Chemical Family: Water Solution - hater is primary ingredient.

\section{SECTION II. HALARDOUS INGREDIENTS}

This water-based lubricant concains $.78 \%$ (wt.)/1.0\% (vol.) isopropanol, which is common rubbing alcohol. The OSHA eight-hour Tide Weighred Average ILV for isopropanol vapor in air is $400 \mathrm{ppm}$. Large quancicies of lubricant ( $>1$ quart) would have to be fully evaporated in small closed areas ( $<10$ cu. merers). to reach these vapor concentration levels which are considered safe. There are no orher OSliA or ACGIH threshold limit values for the product or its other ingredients. 
MSDS \#15321.

SECIIDI III. PHXSICAL DATA

Appearance: A transparent, colorless gel with a faint isopropariol odor.

Boiling Point: $208^{\circ} \mathrm{F}\left(98^{\circ} \mathrm{C}\right)$

Vapor Pressure (m $\mathrm{mg}): 18$ ma $72^{\circ} \mathrm{F}$

Vapor Density $($ Air $=1): .9$ to 1.1

Specific Gravity $\left(\mathrm{H}_{2} \mathrm{O}=1\right): .98$

Solubility in water: Infinite

Viscosity: $40,000-80,000$ cps.

Percent Volatile (Weight): $99.2 \%$

Percent Water (Weight): $98.4 \%$

Ignirfon Temperature: None

$\mathrm{pH}: 6.5-8.5$

SECTION IV. FIRE \& EXPLOSION HAZARD

Flashpoint: No flash via COC.

Flammable Limits: Product is not flamable.

Extingulshing Media: Does not epply.

Special Procedures: Does not apply.

Unusual hazards: Sealed container can build pressure when exposed to high heat.

Hazardous Decomposition Products: High temperature steat, potentially carbon monoxide and carbon dioxide. 
Stability: Excellent. No special handing or condicions to avoid.

:azardous Polymerization: hill not occur.

Incompatibilicy: Avoid concact with waterials which react with water.

SECTION VI. HEALTH YSAZARD

Threshold Limit Value: None established for POLYGATER ${ }^{\ominus}$ G.

Ingestion Razard: Material contains .78\% (wt.) isopropanol with oral ID 50

( $\mathrm{rat}$ ) greater than $5.8 \mathrm{~g} / \mathrm{kg}$. Yaterial contains less than $.4 \%$

carboxyvinyl polyeers with oral LD50 ( $r a t)$ greater than $4 \mathrm{~g} / \mathrm{kg}$.

Ingestion of $100 \mathrm{ml}$. of isopropanol can be $f a r a l$ in humans. This is the equivalent of eating over tio gallons of POLYWATER $G$. No effect is expected on ingestion of swall quantiries.

Inhalation Razard: No inhalation hazard expected with water/isopropanol vapor in nordally ventilated areas. Hich.large quantities of spilled lubricant in hot, closed areas, isopropanol vapors could reach undesirable concentrations (>800 pp⿴囗). Isopropanol has good warning properties (mild irritation of eyes, nose and throat) at vapor concentracions less than 400 ppl. At high concentration, isopropanol way induce wild rarcosis, which is usually transient.

Skin \& Eye Hazard: No deral coxicity hazard. Contact with POLYhates $G$ way cause skin irritation in some individuals. The isopropanol content is an eye irritanc.

Effects of Exposure: No adverse health effects are expected when POLYHATER $G$ is used consistent with good industrial hygiene practice. lo known medical conditions are aggravated by exposure.

First Aid:

Ingestion: No first aid expected to be required. On ingestion of large quantitles or if difficultles arise, contact a physician.

Inhalation: io first ald expected to be required. If headache or dizziness occurs, wove the victin to fresh alr. If problems continue, contact a physician.

Skin Irrication: Wash area thoroughly with soap and water. If irritation continues, obtain medical attention.

Eye Contact: Flush eyes with water for 15 winutes. If irritation continues, seek medical attention.

Carcinogenic Scatus: POLYWATER ${ }^{\otimes} G$ is not known to be carcinogenic and is not lisced nor are any of lis components listed by IARC, NT? Or OSHA. A. 3 
Spill or Leak Procedure: POLYTATER ${ }^{\circ} G$ is extremely slippery. It should be washed, swept or squeegeed from floor using wet mops. Oxidizing agents, such as household bleach, can also be used to elininate the slippery character. Outside, spilis should be covered with sand, dirt, gravel or calciun chloride.

Haste Disposal Method: Dispose of waste in accordance with local, state and federal regulations. For waste disposal purposes, POLYWATER ${ }^{\Theta} G$ is not defined or designated as hazardous.

Precautions in Handling \& Storing: Keep product containers closed when not in use.

Special Precautions: Avoid splils and clean then up imediately when they occur. Product is very slippery.

\section{SECTION VIII. CONTROL MEASURES}

Resplratory Protection: None normally required.

Ventilation: Normal ventilation is adequate.

Protective Clothing: Impermeable gloves should be worn to prevent skin irritation on sensitive individuals.

Eye Protection: Safety glasses recormended.

DOI Shipplng Name: Not applicable.

DoT Hazard Class: Not applicable.

DOT Label: Not applicable.

ON/RA Hazard: Not applicable.

For domestic transportation purposes, this product is not defined or designated as a hazardous material by the U.S. Department of Transportation. 


\section{Distribution}

No. of

Copies

OFFSITE

2 DOE/Office of Scientific and Technical Information

$1 \quad$ K. O. Pasamehmetoglu Los Alamos National Laboratory P. O. Box 1663

Los Alamos, NM 87545

\section{ONSITE}

4 DOE Richland Operations Office

Public Reading Room

RL Docket File (2)

C. R. Groendyke

Los Alamos National Laboratory

J. R. White

H5-09

17 Westinghouse Hanford Company

H: Babad

S7-14

R. E. Bauer

T. R. Benegas

W. G. Brown

T. Erickson

G. J. Gauck

S7-14

H5-09

T4-07

T4-07

T4-07
No. of

Copies

G. D. Johnson

S7-14

C. M. Keller

H5-68

N. W. Kirch

R2-11

P. F. Kison

T4-07

L. S. Krogsrud

T4-07

D. C. Larsen

T4-07

D. E. Legare

H5-57

J. W. Lentsch

S7-14

J. E. Meacham

S7-14

C. P. Shaw

S2-24

T. J. Volkman

28 Pacific Northwest National Laboratory

J. M. Bates

K7-15

J. W. Brothers

K9-20

S. A. Bryan

P7-25

L. L. Burger

P7-25

D. M. Camaioni

K2-38

C. D. Carlson

P7-25

W. C. Cosby

A. L. Doherty

K7-10

R. T. Hallen

K8-34

F. E. Panisko

P8-38

R. D. Scheele, (10)

P8-34

R. L. Sell

P7-25

P7-25

C. W. Stewart

K7-15

J. M. Tingey

P7-25 